\section{PARENTAL REACTIONS TO BIRTH OF A HANDICAPPED CHILD}

DeAr Sir,

In their article, 'Marital Stability following the Birth of a Child with Spina Bifida' (Journal, July I977, 131, pp 79-82), Tew, Laurence, Payne and Rawnsley conclude in their summary that 'the divorce rate for families with a surviving child was found to be nine times that for the local population ... On our calculations, the data presented by the authors show that, on the contrary, the divorce rate in the parents of a surviving spina bifida child is about the same as in the general population and this is in line with other published work (Dorner, 1975; Martin, I975), to which, unfortunately, the authors do not refer.

Our view is based on the following observations about the above paper.

I. The rate of 'IO3 divorces per I,000 married persons per year' which the authors calculate for the parents with a surviving spina bifida child is in fact the number of persons becoming divorced per 1,000 married persons over the period $1964-1974$, and is compared with a rate of ' 15 divorces per 1,000 married persons per year'. This latter rate is more properly that of persons becoming divorced per 1,000 married population per year. It is misleading to compare the annual divorce rate available for the general population with the cumulative I0-12 year rate of the spina bifida parents. The authors acknowledge that the comparison 'cannot be attempted' but then proceed to draw conclusions from just such a comparison.

2. In order to correct the national divorce rate figure for divorces amongst childless couples, Tew et al simply reduce the rate of 15 divorces per I, ooo married persons per year by 25 per cent to I I per I, ooo because, they argue, one quarter of all divorces are to childless couples. This is an over-correction, because it does not take account of the change in size of the base population when childless couples are removed from it.

3. We have been unable to trace the reference given as the source of the South Wales divorce rate. The most likely source for this would be Office of Population Censuses and Surveys (1973). However, Table 13 of this publication would only allow the calculation of a rate, for example, of divorced persons per 1,000 married persons in $197 \mathrm{I}$, and not the 'divorces per I, ooo marriages' reported by Tew et al, and which they imply to be a yearly rate by its comparison with a true yearly national rate.
4. The authors say that comparable cohort data from the general population do not exist, but Leete (1976) gives a national figure of $9 \mathrm{I}$ divorces by 1974 out of 1,000 marriages in 1963 , for those where the wife was under 45 at the time of marriage. The figure given for 1959 marriages is 100. Assuming that in Tew et al's study most of the marriages were not long before the birth of the spina bifida child, the 1963 figure is the most appropriate (it also represents the lowest possible divorce rate for comparison purposes), and when using the Tew et al's correction for childless divorces (which we have shown above to be an over-correction) a rate of 68 divorces per I,ooo marriages is obtained. This can be contrasted with the rate of 103 divorces per 1,000 marriages found for parents of a surviving spina bifida child.

The rate of divorce in the parents of a surviving spina bifida child is therefore at most $I \cdot 5$ and not 9 times that in the general population. The equivalent comparisons for parents of a dead spina bifida child give a rate of $\cdot 4$ to $\cdot 5$ times that of the general population.

In view of these methodological objections we consider that serious doubt is cast upon the general conclusion that when the handicapped child survives marriages are placed at great risk. Further study is clearly merited by the finding that where the child dies marital breakdown occurs less frequently (on our analysis) than in the general population.

Jim Stevenson

Philip Graham

Academic Department of Child Psychiatry,

Steven Dorner

Department of Psychological Medicine,

Hospital for Sick Children,

Great Ormond Street,

London WCI

\section{References}

Dorner, S. (1975) The relationship of physical handicap to stress in families with an adolescent with spina bifida. Developmental Medicine and Child Neurology, I7, $765-76$.

Leete, R. (1976) Marriage and divorce. Population Trends, 3, 3-8.

Martin, P. (1975) Marital breakdown in families of patients with spina bifida cystica. Developmental Medicine and Child Neurology, 17, 757-64.

Office of Population Censuses and Surveys (1973) Census 1971, England and Wales. County Report. Glamorgan Part $\mathrm{I}$. London: HMSO. 